\title{
防水上の観点からの損傷の深さ測定による 建築用シーリング材の耐候性評価法の提案 \\ PROPOSAL OF WEATHERABILITY EVALUATION METHOD OF CONSTRUCTION SEALANT FOR WATERPROOFING BY MEASUREMENT OF THE DEPTH OF FAILURE
}

\author{
伊藤彰彦*, 竹本喜昭**, 田中享二*** \\ Akihiko ITO, Yoshiaki TAKEMOTO and Kyoji TANAKA
}

\begin{abstract}
Weatherability of construction sealants was studied from the viewpoint of waterproofing. First, the outdoor exposure tests of 12 sealants were carried out for 10 years at Miyakojima, Choshi and Asahikawa in Japan, using the newly developed specimen which is able to reproduce wide range of sealing joint width in the same specimen. The joint width was moved once a month through exposure duration. The two kinds of cracking were observed such as shallow cracking on the surface of a bead and deep cracking at the close portion of it to the adhered face in the specimen. The depth of cracks was measured at the three positions of 0,15 and $25 \%$ deformation rate in a specimen by a microscope and a taper gauge. Deep cracking is considered to be fatal rather than shallow surface cracking for waterproofing performance, and the weatherability estimation method of sealants was proposed.
\end{abstract}

Keywords: Sealants, Weatherability, Compression and extension cycle, Out-door exposure, Depth of Crack, Depth of Failure シーリング材，而候性，圧縮伸長サイクル，屋外暴露，ひひ割れの深さ，損傷の深さ

\section{1 はじめに}

建築用シーリング材（以下、シーリング材という。）は外壁の目地 に充填され水密・気密を確保するための材料であり、露出状態で使 用されることが多い。このためシーリング材は、太陽光、外気温お よび降雨などの気象による負荷を受ける。さらに、外壁の目地に充 填されたシーリング材は、建物外壁の動きに追従して変形させられ るため、目地の拡大・縮小によるムーブメントの負荷も受ける。従 って、シーリング材は気象とムーブメントの複合的な作用により、 時間の経過とともに徐々に劣化していくことになる。

そのため建物に長期間使用されているシーリング材には表面にひ び割れが発生している場合が多い。また、目地の拡大・縮小による ムーブメントの負荷により接着破壊や凝集破壊が発生している場合 もある。ひび割れの成長、接着破壊や凝集破壊の進行は、水密・気 密機能を低下させることになるため、これらの損傷の状態は劣化進 行の重要な評価尺度となる。

ところで一般に、シーリング目地の深さは $10 \sim 20 \mathrm{~mm}^{1)}$ であり、 それほど厚いものではない。ひび割れがシーリング材表面から裏面 まで達すると、シーリング目地の水密性、気密性が失われる。その ため深さ方向への劣化の評価は、防水の観点から最も基本となる。 本研究では、ムーブメントを受けながらウェザリングによる劣化 を調べることができる、目地幅可変型試験体 2)を用いて、各種シー
リング材の動暴露試験を行い、試験体に発生したひび割れ、接着破 壊、凝集破壊などの損傷の深さの 10 年間にわたる観察をもとに、 シーリング材の耐候性を防水性能の損傷度の観点から評価する手法 を開発することを目的とした。

\section{2 既往の研究}

榎本らは、目地幅可変型試験体を用いて動暴露試験を実施し、シ ーリング材の耐候性を表面のひび割れの状態で評価している 2)。こ れは、塗料等の評価のための ISO 規格を参考に、ひび割れを目視で 観察し、ひび割れの量 Q (Quantity) とひび割れの大きさ S (Size) を各々 0 から 5 までの 6 段階で評価し、 $\mathrm{Q} \times \mathrm{S}$ の積值を用いて一元 化し、ひび割れの定量化を行う方法である。これはどちらかという と、美観に影響を与えるシーリング材の表面劣化に力点のおかれた 評価法であり、防水の観点からの評価には適切ではない。

また、Karpati は、気象変化に対応してムーブメントが発生する 屋外暴露用ラックに、アルミニウム被着体によるシーリング目地試 験体を設置し、被着体近傍に発生した外観としての接着破壊と凝集 破壊の進行を評価している 3)。しかし、ひび割れの深さ等、防水性 に関しての評価については触れられていない。

いずれの研究も、ここで行おうとする水密・気密を対象とした深 さ方向の評価はなされていない。
*オート化学工業(侏環境・品質保証部 部長

** 清水建設侏技術研究所 研究員 · 博士 (工学)

*** 東京工業大学 名誉教授.工博
Department Manager, Environment \& Quality Assurance Dept., Auto Chemical Ind. Co., Ltd. Research Engineer, Institute of Technology, Shimizu Corporation, Dr. Eng. Prof. Emeritus, Tokyo Institute of Technology, Dr. Eng. 


\section{3 屋外暴露試験}

\section{1 試験計画}

(1) 試験体

試験には、榎本らが開発した目地幅可変型試験体を用いた 2)。試 験体は、図 1 に示寸ように $15 \mathrm{~mm} \times 15 \mathrm{~mm}$ 、長さ $120 \mathrm{~mm}$ の二本の アルミニウム製の L 型アングルを平行に設置し、その中央位置に回 転軸を設け、シーリング材を充填するために $20 \mathrm{~mm}$ の間隔をあけ、 下地板に取り付けたものである。この二本のアルミニウム製アング ルをお互い反対方向に回転させることにより、目地間隔が変えられ るものである。従って一つの試験体で連続的にシーリング材の伸縮 量を変化させることができ、また拡大状態、無変形状態、縮小状態 を作り出すことができるという特長をもっている。

（2）試験に用いたシーリング材

わが国で弾性シーリング材として使用されているもののうち、主 なもの 12 種類を選定した。それらの標準養生後の物性值を表 1 に 示す。

（3）試験体の作製および試験方法

目地幅可変型試験体のアルミニウム製アングルを、互いに平行な 状態で固定し、シーリング材との接着面にはそれぞれ専用のプライ マーを塗布する。塗布後にシーリング材を充填し、JIS A 1439 の条 件に準拠し養生を行った。なお作られるシーリング材の断面は $20 \mathrm{~mm} \times 15 \mathrm{~mm}$ である。

試験手順は以下の通りである。シーリング材の硬化養生後に、図 2 に示寸ようにシーリング材の一方を縮小状態とし、反対側を伸張 状態と寸る。その後アルミニウム被着体の片側に固定板を強制的に 取り付け、その状態で固定する。縮小状態の目地幅は $14 \mathrm{~mm}$ であり、 反対側の拡大状態では $26 \mathrm{~mm}$ になるようにした。これはシーリング 材ではそれぞれ圧縮 30\%、伸張 30\%に相当する。

この状態で屋外暴露を開始し、1 ケ月毎に固定板の位置を左右変

表 1 シーリング材の種類と標準養生後の物性値

\begin{tabular}{|c|c|c|c|c|}
\hline \multirow[t]{2}{*}{ 種類 } & \multirow[t]{2}{*}{ 記号 } & \multicolumn{3}{|c|}{ 標準養生後の物性値注) } \\
\hline & & $\begin{array}{c}50 \% \\
\text { モジュラス } \\
\left(\mathrm{N} / \mathrm{mm}^{2}\right)\end{array}$ & $\begin{array}{c}\text { 最大 } \\
\text { 引張応力 } \\
\left(\mathrm{N} / \mathrm{mm}^{2}\right) \\
\end{array}$ & $\begin{array}{c}\text { 最大荷重時 } \\
\text { の伸び率 } \\
(\%)\end{array}$ \\
\hline 2 成分形沙コーン系 & SR2 & 0.14 & 0.81 & 1170 \\
\hline $\begin{array}{l}1 \text { 成分形変成沙コーン系 } \\
(\text { 汎用夕イプ })\end{array}$ & MS1-A & 0.12 & 0.56 & 560 \\
\hline $\begin{array}{l}1 \text { 成分形変成沙コーン系 } \\
\text { (高耐候夕イプ) }\end{array}$ & MS1-B & 0.10 & 0.65 & 650 \\
\hline $\begin{array}{l}2 \text { 成分形変成沙コーン系 } \\
\text { (汎用タイプ) }\end{array}$ & MS2-A & 0.15 & 0.49 & 650 \\
\hline $\begin{array}{c}2 \text { 成分形変成沙コーン系 } \\
\text { (応力緩和夕イプ })\end{array}$ & MS2-B & 0.15 & 0.86 & 770 \\
\hline 1 成分形ポリサルアイイド系 & PS1 & 0.08 & 0.45 & 900 \\
\hline 2 成分形ポリ水アイド系 & PS2 & 0.12 & 0.50 & 850 \\
\hline 2 成分形ポリイリブチレ系 & IB2 & 0.11 & 0.38 & 490 \\
\hline 1 成分形ポリウレタ⿺系 & PU1 & 0.14 & 1.03 & 950 \\
\hline 2 成分形ポリウレ多系 & PU2 & 0.15 & 0.53 & 570 \\
\hline 2 成分形乃㖄多系 & UA2 & 0.12 & 0.68 & 860 \\
\hline 1 成分形アクリル系 & $\mathrm{AC} 1$ & 0.11 & 0.15 & 470 \\
\hline
\end{tabular}

注）JIS A 1439 に準拠して測定した。
更することによって、屋外の気象環境に曝しながらシーリング材の 伸縮繰返しを行った。

\section{2 屋外暴露地}

試験体は南向き $45^{\circ}$ 傾斜暴露台に設置し、暴露地は北海道 (北方 建築総合研究所・旭川屋外暴露場)、本州中央部（日本ウェザリング テストセンター・銚子屋外暴露場)、沖縄（同・宮古島屋外暴露場） の日本国内の気象環境が異なる 3 地点とした。各暴露地の暴露状況 を写真 1 に示す。暴露試験は 2002 年 10 月に開始され、現在まで 10 年を経過している。各暴露地の暴露期間中の気象データを表 2 に示す。

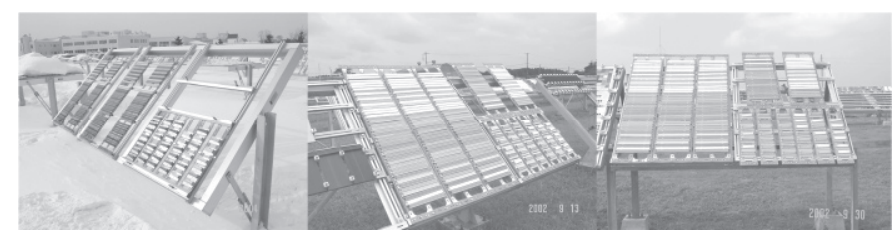

旭川

銚子

宮古島

写真 1 各暴露地の暴露状況

表 2 暴露地の気象データ

（2002.10～2012.09 までの 10 年間）

\begin{tabular}{|c|c|c|c|}
\hline 暴露地 & 旭川 & 銚子 & 宮古島 \\
\hline 月間平均最高気温 $\left({ }^{\circ} \mathrm{C}\right)$ & 28.8 & 30.5 & 33.1 \\
\hline 月間平均最低気温 $\left({ }^{\circ} \mathrm{C}\right)$ & -14.8 & 1.4 & 14.2 \\
\hline 10 年間積算降水量 $(\mathrm{mm})$ & 10,308 & 17,632 & 20,221 \\
\hline $\begin{array}{c}10 \text { 年間積算全日 射量 } \\
\left(\mathrm{MJ} / \mathrm{m}^{2}\right)\end{array}$ & 43,472 & 50,553 & 53,434 \\
\hline
\end{tabular}

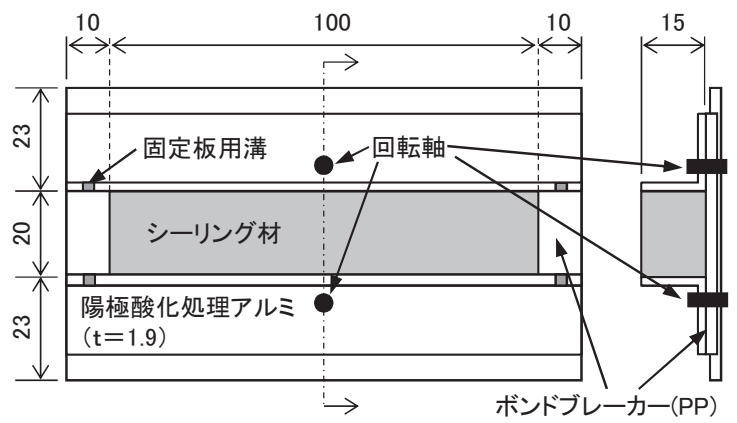

図 1 目地幅可変型試験体

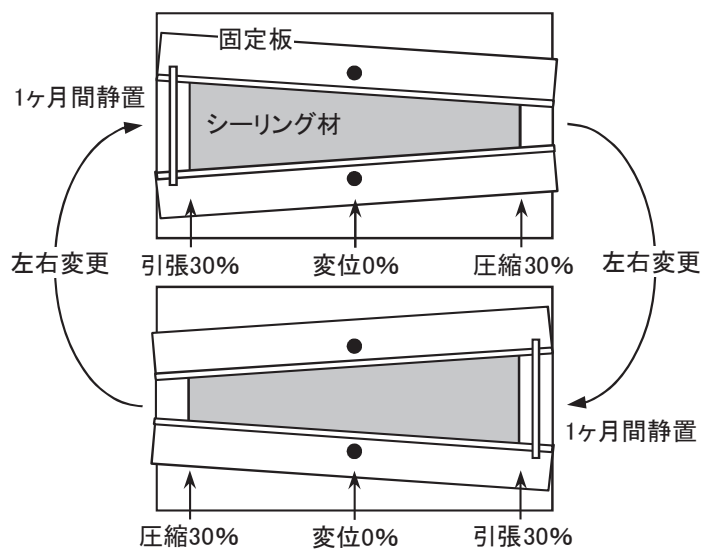

図 2 目地へのムーブメントの与え方 


\section{3 評価項目と方法}

ひび割れが表面から裏面まで貫通すると漏水するという防水上の 観点から、シーリング材表面のひび割れと被着体近傍の損傷の深さ を調べた。

（1）シーリング材表面のひび割れ深さ（Dc 值， $\mathrm{mm}$ ）

デジタル測長機付きの光学顕微鏡（倍率 100 倍）を用いて、測定 位置におけるひび割れについて 3 ケ所測定し、その最大值をひび割 れ深さとした。ひび割れ深さは、初めに対象とするひび割れの周囲 のシーリング材表面の焦点距離を測定し、次にそのひび割れの底の 焦点距離を測定した後、これらの焦点距離の差をひび割れ深さとし て求めた ${ }^{4)}$ 。測定は伸長状態で行い、写真 2 に示寸伸長率 $0 \%, 15 \%$, $25 \%$ 目地の長さ方向を直交する各伸長率の位置で測定した。

（2）被着体近傍の損傷の深さ（Df 值， $\mathrm{mm}$ )

テーパーゲージを用いて、アルミニウム製アングルとシーリング 材の間で、シーリング材の破壊またははく離が発生している場所の 損傷の深さを測定した。測定は伸長状態で行い、写真 2 に示寸伸長 率 $0 \% ， 15 \% ， 25 \%$ の位置で両側の被着体近傍で測定し、大きい方 の数值を損傷の深さとした。

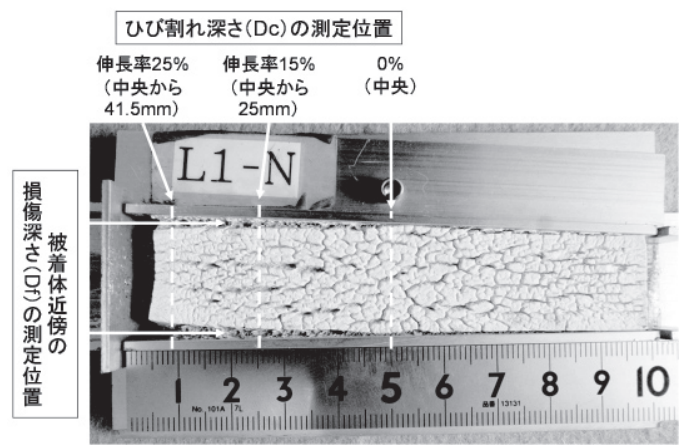

写真 2 ひび割れ深さ（Dc 值）と被着体近傍の損傷深 さ（Df 值）の測定位置

\section{4 屋外暴露 10 年後の結果と考察}

屋外暴露 10 年後の試験体の写真を写真 3 に示寸。なお、劣化は ほぼ左右対称に生じるため、写真と評価位置は試験体の片側半分と している。なお目地の一般部分と被着体近傍では損傷の程度が異な るため、これを分けて検討する。

4.1 一般部分のひび割れ深さ (Dc 值, $\mathrm{mm}$ )

屋外暴露 10 年間の各暴露地における伸長率ごとのひび割れ深さ (Dc 值) の結果を図 3 に示す。

SR2 はいずれの暴露地でも全ての測定位置でひび割れは発生し なかった。ひび割れが発生したシーリング材では、全体として伸長 率が大きくなるに従ってひび割れが深くなる傾向であった。

\section{2 被着体近傍の損傷深さ ( Df 値, $\mathrm{mm}$ )}

屋外暴露 10 年間の各暴露地における伸長率ごとの損傷深さ（Df 值）の結果を図 4 に示寸。

ムーブメント無しの $0 \%$ 位置では、全てのシーリング材で被着体 近傍の損傷は発生しなかった。ムーブメント有りの伸長率 $15 \%$ よ び $25 \%$ では、IB2 以外ではいずれかの暴露地で被着体近傍の欠陥が 認められた。多くの場合、その深さは目地の一般部分のひび割れ深 さ $(\mathrm{Dc}$ 值 $)$ より著しく大きい值であった。
この理由の考察のために、シーリング材内の応力分布の概要を 2 次元 FEM 弾性解析により調べた。図 5 に $25 \%$ 引張・圧縮時の応力 分布を変形図とともに示す。目地拡大時にはシーリング材の隅角部 に大きな引張力が、また縮小時には同様に隅角部に大きな圧縮力が 生じている。すなわち試験期間中、隅角部が最も大きな振幅の力学 的負荷を受けていたと考察される。シーリング材はこの状態で屋外 暴露によるウェザリングを受けるため、被着体近傍での損傷深さが 一般部より大きくなったものと思われる。なお、被着体近傍での損 傷深さが大きくなった位置では、一般部分のひび割れ深さが小さく なる傾向が見られた。これは、シーリング材が被着体から離れるこ とで、シーリング材表面に伝わる応力が減少したためと考えられる。
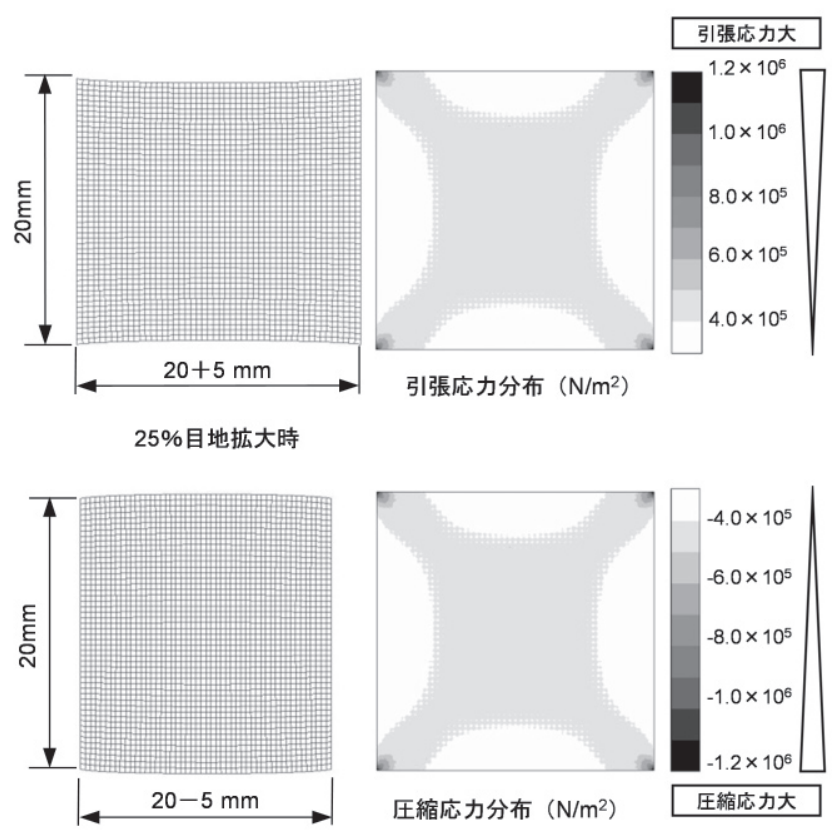

$25 \%$ 目地縮小時

（ヤング率 : $1.34 \times 10^{6} \mathrm{~N} / \mathrm{m}^{2}$ ，ポアソン比 : 0.45，50×50メッシュで計算）

図 5 FEM 解析による応力解析結果

\section{3 暴露地による影響}

一般部分のひび割れ梁さ（Dc 值）は、全体的に、宮古島＞銚子> 旭川の順で深くなる傾向が見られた。ひび割れ梁さが最も大きかっ たのは、宮古島暴露の AC1 であり、伸長率 $25 \%$ 位置におけるひび 割れ深さの值は $10 \mathrm{~mm}$ であった。

一方、被着体近傍の損傷深さ（Df 值）に関しては、宮古島での損 傷が大きい試験体は MS2-Aおよび PU2 であったが、MS2-B, PS1, PU1 と AC1 では異なった傾向が見られ、旭川、銚子での損傷が著 しかった。 MS2-B と AC1 は旭川と銚子暴露の伸長率 $25 \%$ の位置で は $15 \mathrm{~mm}$ の貫通欠陥が見られたが、宮古島では、貫通には至らなか った。一般にシーリング材の主成分である有機ポリマーは低温にな るほど硬くなる性質を持っているため、低温環境ほどモジュラスが 高くなる。このため、力学的挙動が加えられると宮古島より旭川及 び銚子の方が厳しい環境となったものと推定される。 


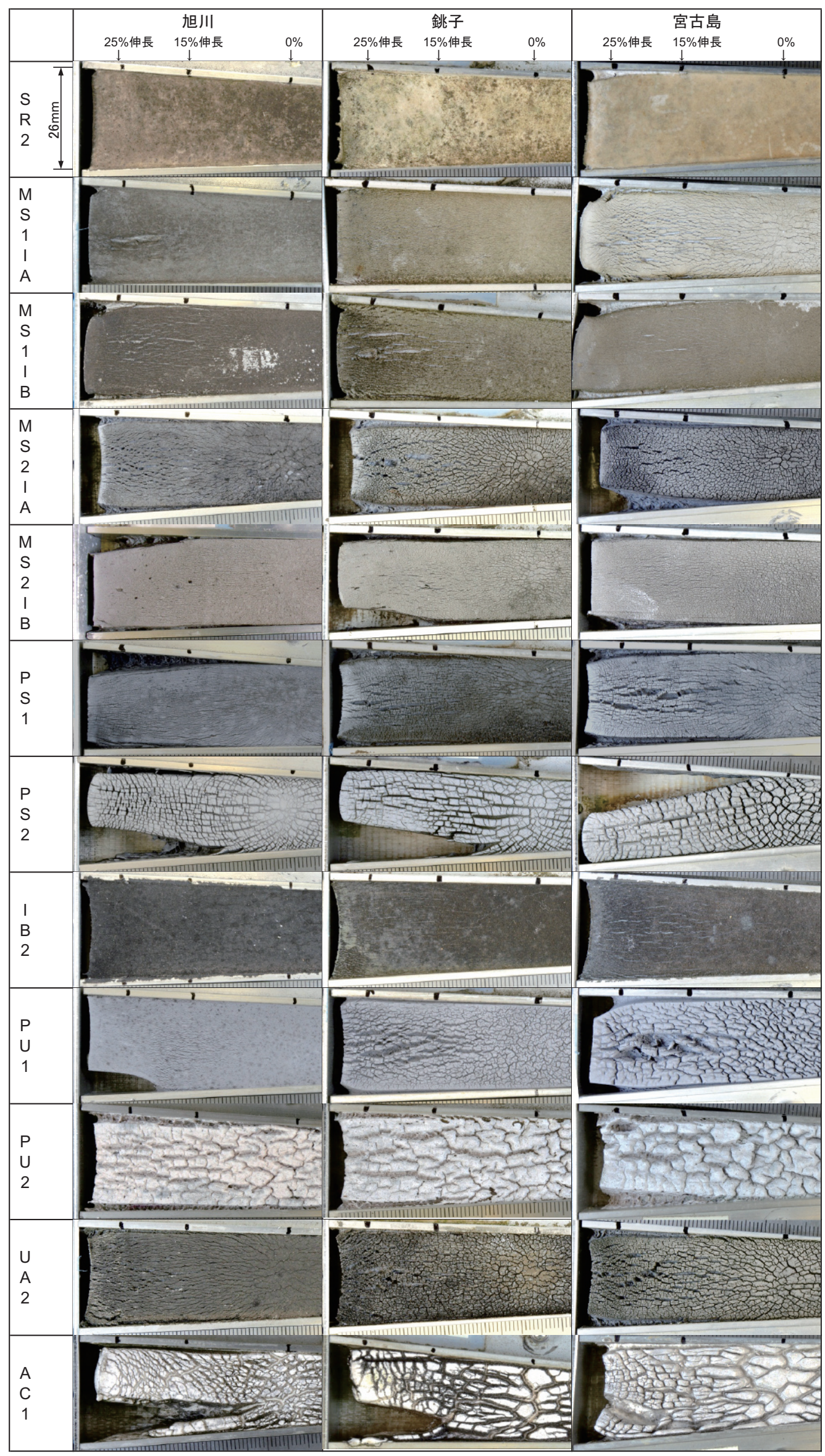

写真 3 屋外暴露 10 年後の試験体 

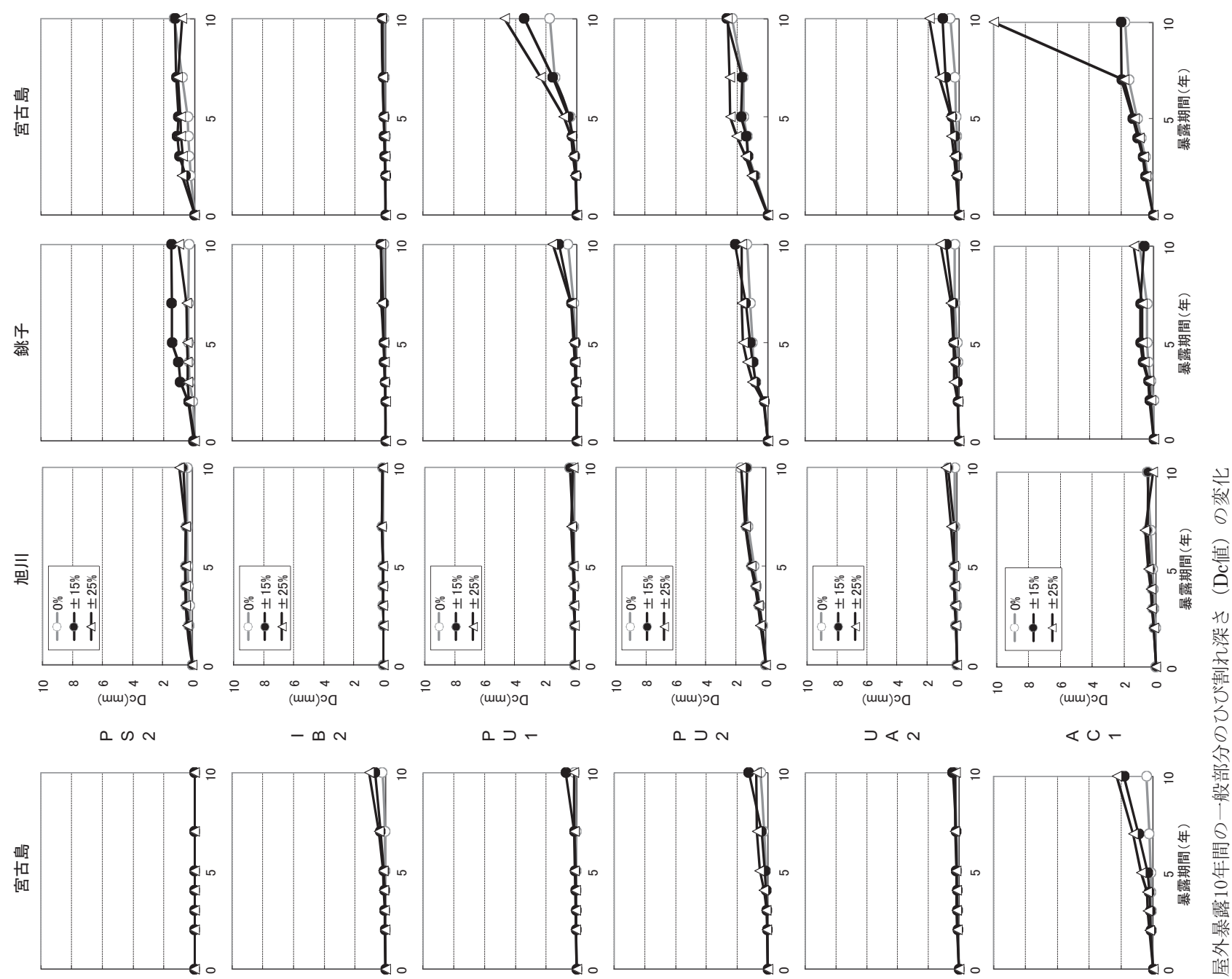

ด $\supset$ N
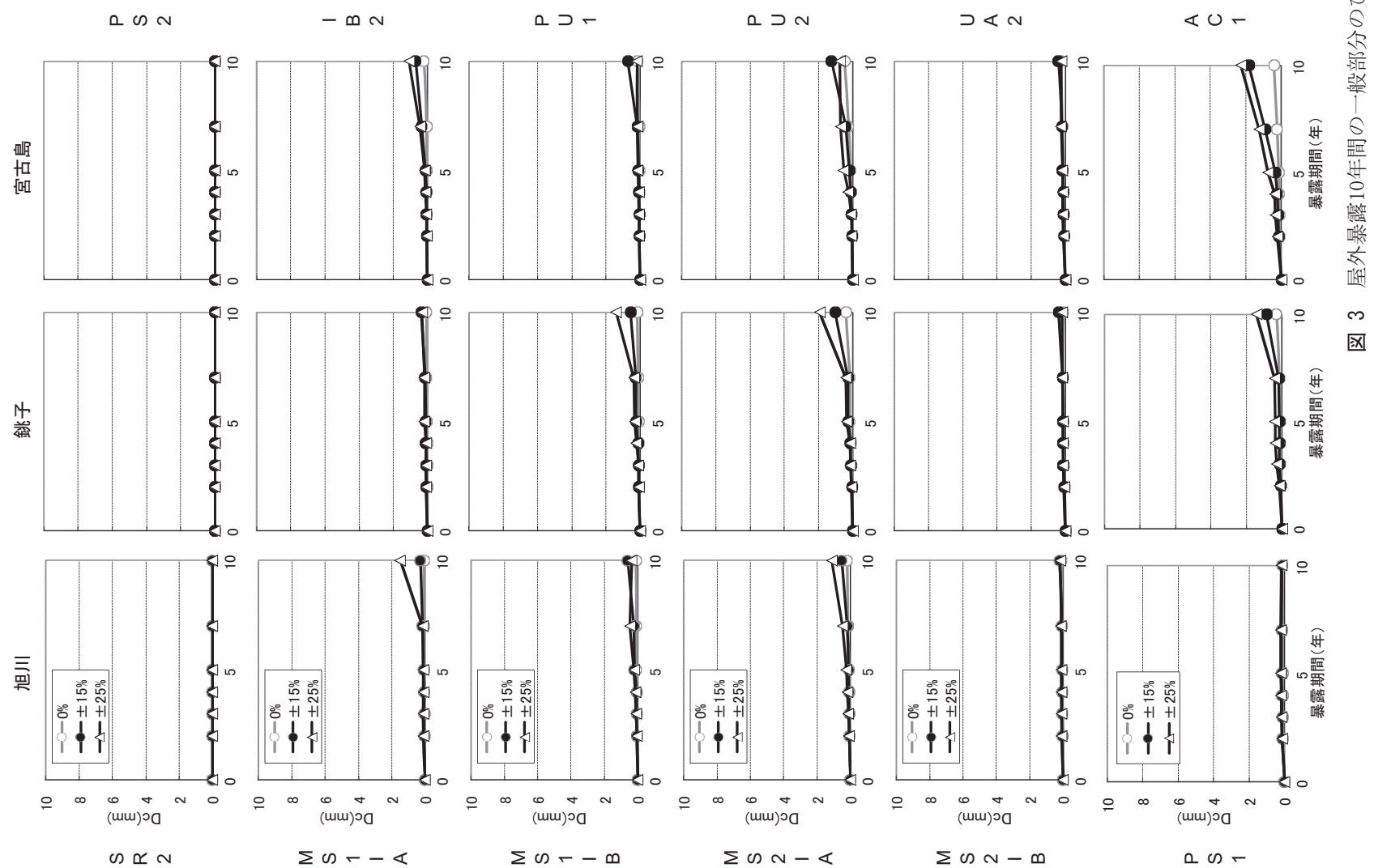

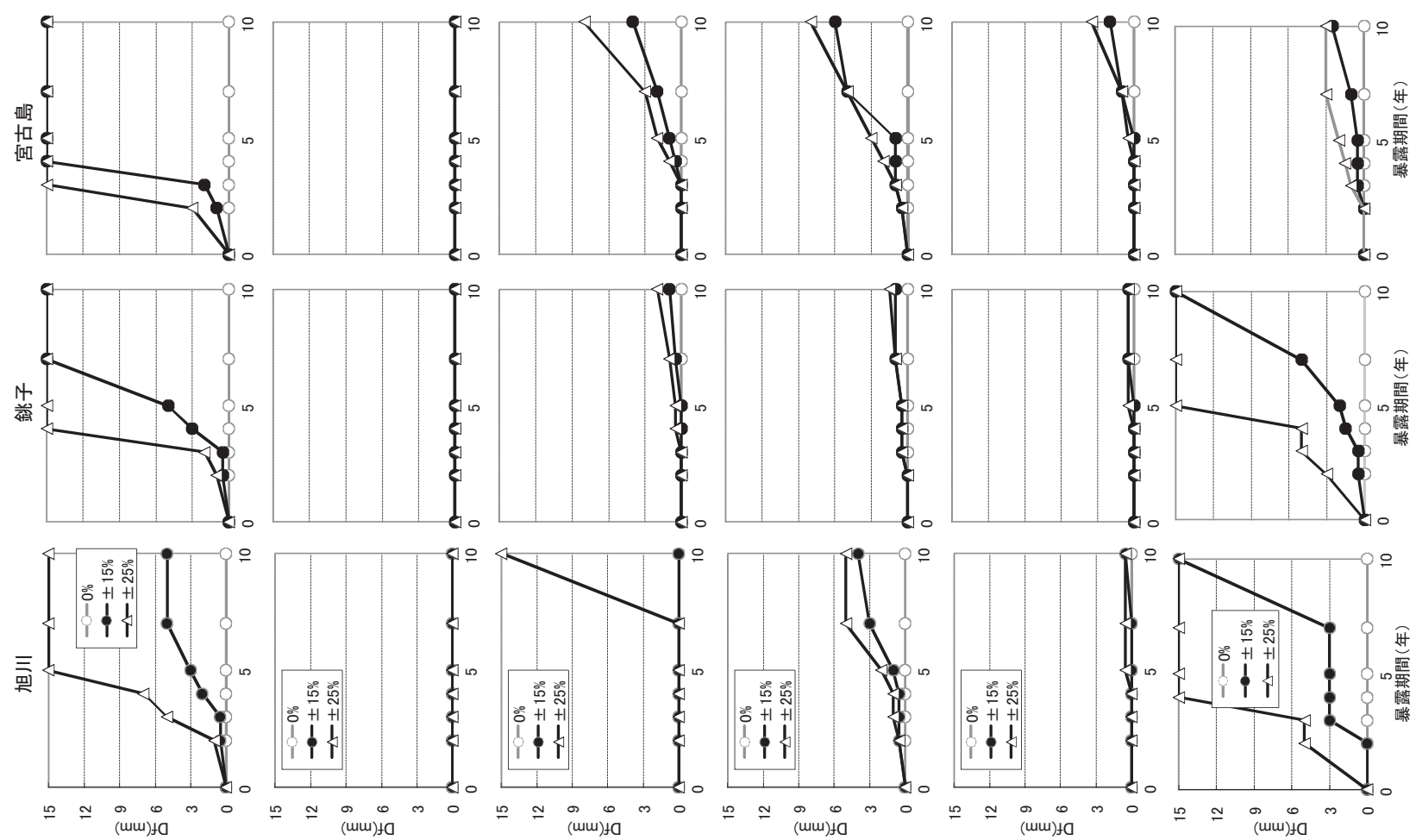

- $\backsim$

$-\infty \sim$

ㄷ

๑

$\supset \ll \sim$
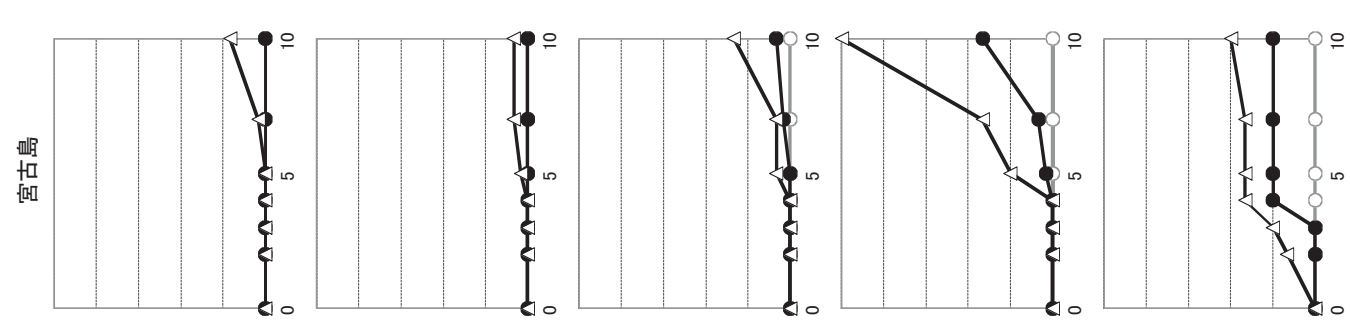

$<0-$
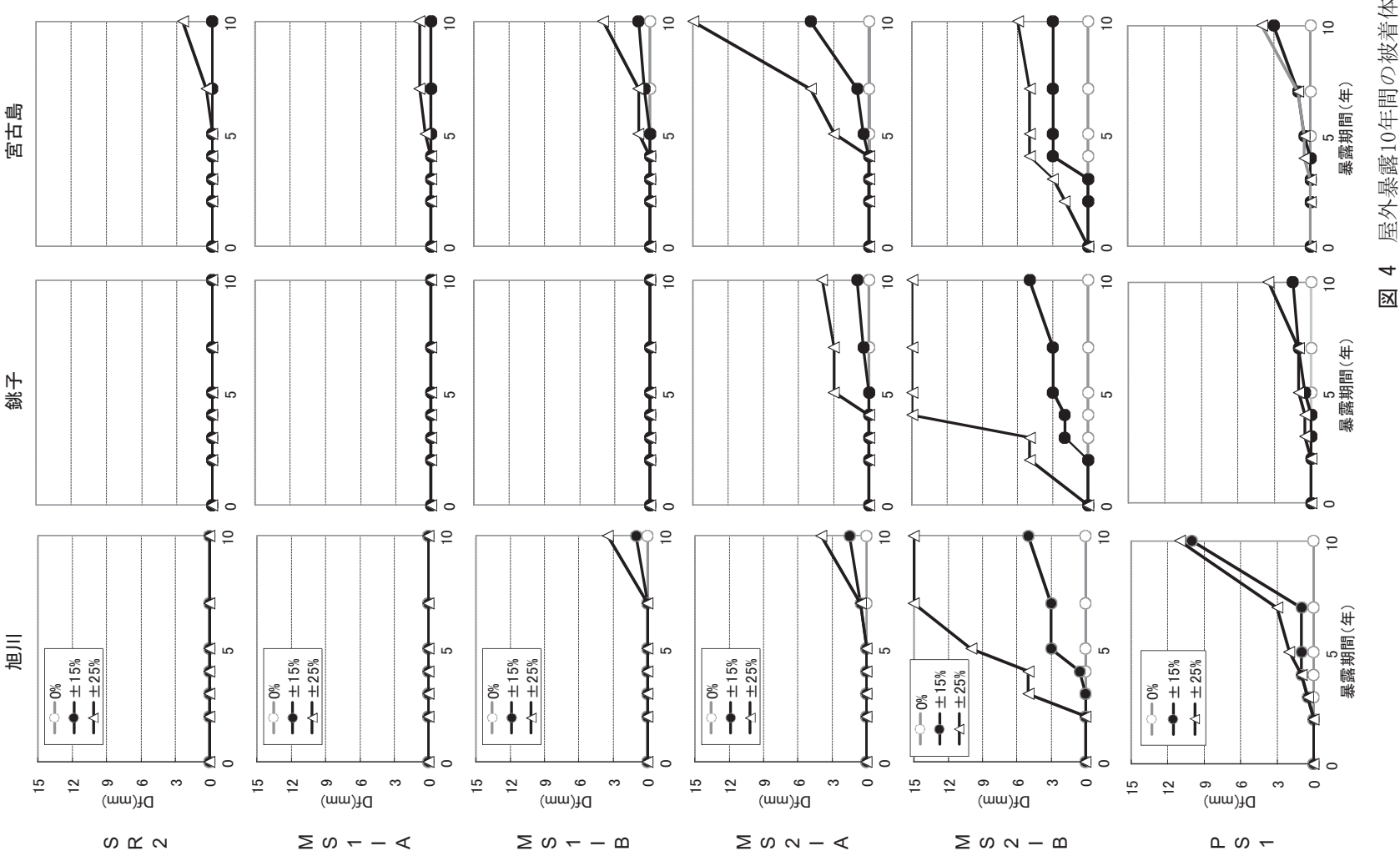

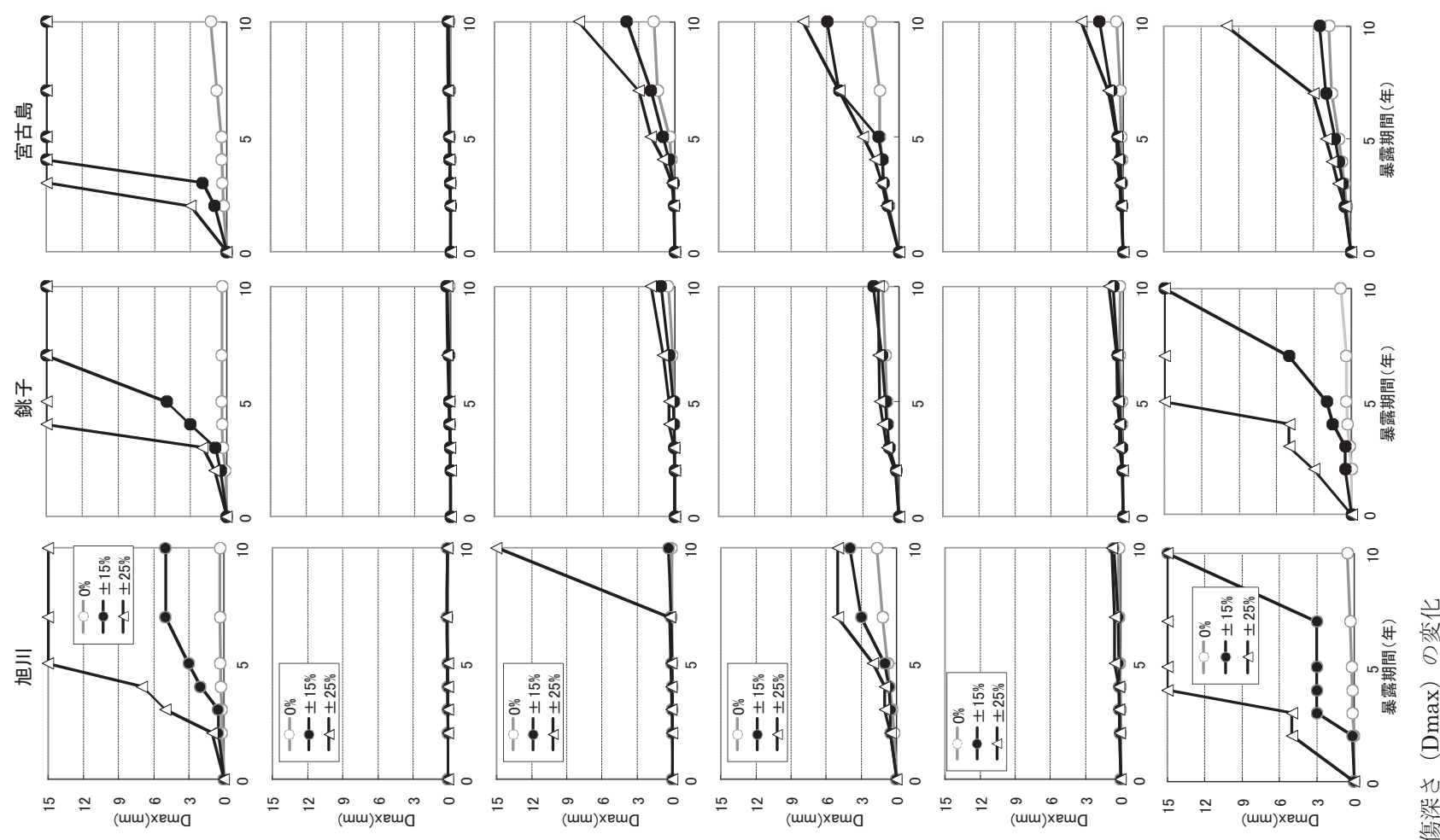

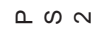

$-\infty \sim$

๑ ว -

$\triangle \supset N$

$\supset \varangle N$
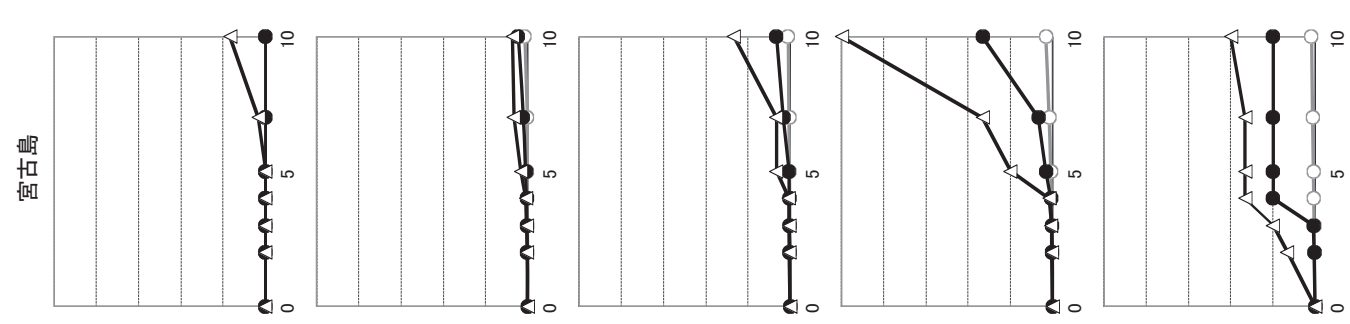

$<0-$
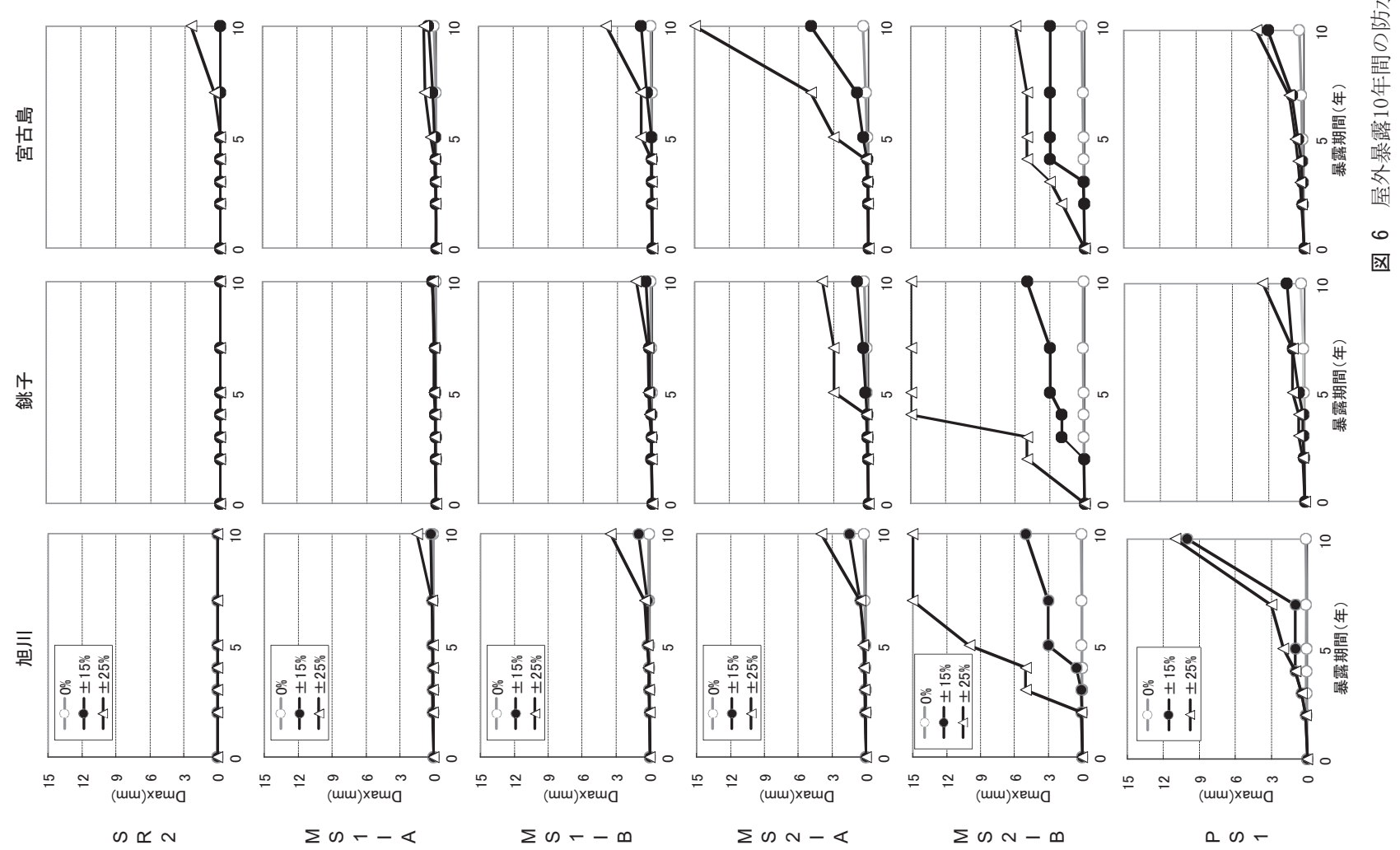


\section{$5 \quad$ 防水性能の観点からの損傷度評価尺度の考察}

屋外暴露 10 年後の目地の一般部分のひび割れ深さは最大で $10 \mathrm{~mm}$ であり、防水上問題となる深さには達していなかった。一方 被着体近傍では、損傷深さは最大で $15 \mathrm{~mm}$ であり、ほぼ貫通してい る状態であった。また発生している試験体では、概して一般部分の ひび割れ深さより著しく大きかった。従って防水性の評価は、各伸 長率の位置における最大深さを尺度とするのが妥当と考えられた。

以上のことから、以下に建築用シーリング材の耐候性を、防水性 能の劣化の観点から評価する手法を提案する。

(1) 式に示す一般部分のひび割れ深さ（Dc 值）と被着体近傍の 損傷深さ（Df 值）のいずれか大きい方の值をその伸長率における防 水損傷深さ（Dmax）とし、防水性能の評価尺度とする。

防水損傷深さ（Dmax） $=\operatorname{Max}(\mathrm{Dc}$ 值 or Df 值 $)$

この方法により求めた防水損傷深さの変化を、図 6 に示す。これに より防水の観点から見た時のシーリング材の耐侯性の評価が可能と なり、今回の動きをあたえた暴露試験では、2 成分形シリコーン系、 2 成分形ポリイソブチレン系のものは優れた耐侯性をもっているこ とが明らかとなった。

\section{6 結論}

建築用シーリング材の耐候性を、防水性の劣化の観点から評価し た本研究の結論は、以下の通りである。

（1）一般部分のひび割れ深さ（Dc 值）は、0〜 $25 \%$ 目地伸縮を付 与した屋外暴露試験の 10 年後で、最大のものでも $10 \mathrm{~mm}$ であ り、直ちに防水上の損傷となる深さには達していなかった。

（2）被着体近傍の損傷深さ (Df 值) は著しく大きな值のものがあり、 いくつかの試料では防水の観点からはその機能を失った状態 のものもあった。

（3）防水の観点からは被着体近傍の損傷深さの評価が不可欠であ る。

（4）これらを基に、ひび割れ深さ（Dc 值）と被着体近傍の損傷深さ （Df 值）のいずれか大きい方の值を防水損傷深さ（Dmax）と した、防水性の観点からのシーリング材の耐候性評価方法を提 案した。

\section{7 今後の課題}

防水性能上の観点から耐候性を評価した結果、図 6 の結果に示寸 ようにいくつかの試料（MS2-B, PS-1, PU-1, AC-1）では寒冷地 のほうが厳しい結果となるものもあることが明らかになった。防水 の観点から寒冷地の方が厳しいものもあるという結果は、従来の気 温が高く紫外線量が大きい南方地域で劣化が著しいとする従来の知 見とは異なるものであり、そのメカニズムについては今後の重要な 課題である。

\section{謝辞}

本研究は日本建築学会・防水材料耐久性評価試験方法W G の研究 活動の一環として行われました。銚子と宮古島の屋外暴露試験は日 本シーリング材工業会の経済的支援により実施されました。また 実施にあたっては、建材試験センターの清水市郎氏、サンスター
技研の榎本教良氏、日本シーカの清水裕介氏 、日本ウェザリングテ ストセンターの高根由充氏及び久貝安生氏、北海道立北方建築総合 研究所の松村宇氏、に多大なご協力を頂きました。厚く感謝致しま す。

\section{参考文献}

1） 日本建築学会編：外壁接合部の水密設計および施工に関する技術指針・ 同解説, pp. 93-112, 2008

2）榎本教良，伊藤彰彦，竹本喜昭，田中享二 : 建築用シーリング材の耐候 性評価のための新しい試験体及び試験方法, 日本建築学会構造系論文集, 第 604 号, pp. 17-22，2006.6

3) Karpati, K.K. : Weathering of silicone sealant on strain-cycling exposure rack, Adhesive Age, 23, pp. 41-47, 1980

4）伊藤彰彦, 榎本教良, 松村宇, 高根由充, 岡本肇, 清水市郎, 田中享二 : 防水材料の耐候性試験 その 24 クラック深さによる建築用シーリング 材の耐候性評価, 日本建築学会大会学術講演梗概集, A-1, pp. 53-54, 2008

（2012年11月 8 日原稿受理，2013年 1 月10日採用決定） 